\title{
Investigation on the sorption of aluminium in drinking water by low-cost adsorbents
}

\author{
Tony Sarvinder Singh, Bhavik Parikh and KK Pant* \\ Department of Chemical Engineering, Indian Institute of Technology, Delhi Huaz Khas New Delhi 110016, India
}

\begin{abstract}
Aluminium is one of the trace inorganic metals present in drinking water. High aluminium concentrations ( 3.6 to $6 \mathrm{mg} / \ell$ ) may precipitate as aluminium hydroxide affecting aquatic life. Aluminium is also a suspected agent of neurological disorders such as Alzheimer's disease and senile dementia. The present investigation aims at the sorption of aluminium from drinking water using a low-cost adsorbent. Rice husk char and activated rice husk char were prepared and characterised for various physicochemical properties. The performance of rice husk char (RHC) was compared with other low-cost adsorbents for their aluminium removal capacity. The effect of $\mathrm{pH}$, initial concentration, contact time and temperature was studied for adsorption of aluminium from water under batch conditions. The maximum adsorption capacity was observed with rice husk char at an optimal $\mathrm{pH}$ of 4.2. The adsorption of aluminium follows the Freundlich adsorption isotherm. The rate of aluminium adsorption was successfully described by a first-order kinetic model. The thermodynamic study revealed that aluminium adsorption is an exothermic process and the adsorption decreases with an increase in temperature.
\end{abstract}

Keywords: aluminium adsorption; batch; kinetics; thermodynamics; rice husk char

\section{Nomenclature}

$b \quad$ Langmuir constant $(\ell / \mathrm{mg})$

$C_{e} \quad$ Equilibrium aluminium concentration in solution $(\mathrm{mg} / \ell)$

$C t \quad$ Aluminium concentration in solution at time $\mathrm{t}(\mathrm{mg} / \mathrm{l})$

$\Delta G^{o} \quad$ Gibb's free energy $(\mathrm{kJ} / \mathrm{mol})$

$\Delta H^{o} \quad$ Enthalpy change $(\mathrm{kJ} / \mathrm{mol})$

$K \quad$ Freundlich constant $\left(\mathrm{mg}^{1-1 / n} / \mathrm{g}^{1 / \mathrm{n}}\right)$

$k_{1} \quad$ First-order rate constant (per hour)

$k_{2} \quad$ Pseudo second-order rate constant $(\mathrm{g} / \mathrm{mg} \cdot \mathrm{h})$

$n \quad$ Freundlich constant (dimensionless)

$Q \quad$ Langmuir constant (mg/g)

$q_{e} \quad$ Amount of solute uptake per unit mass of adsorbent at equilibrium $(\mathrm{mg} / \mathrm{g})$

$R \quad$ Gas constant $(\mathrm{J} / \mathrm{mol} \cdot \mathrm{K})$

$\Delta S^{o} \quad$ Entropy change $(\mathrm{J} / \mathrm{mol} \cdot \mathrm{K})$

$T$ Temperature $(\mathrm{K})$

$t \quad$ Time (h)

\section{Introduction}

About $8 \%$ of the earth's crust consists of aluminium. This element is the most abundant metal naturally present in air, soil and water. Consequently, environmental exposure to aluminium is potentially possible. Its ingestion is unavoidable since aluminium compounds are added not only to most water supplies but also to many processed foods and medicine (Denizli et al., 2003).

Aluminium-based coagulants such as aluminium sulphate $\left(\mathrm{Al}_{2}\left(\mathrm{SO}_{4}\right)_{3}\right)$ or poly-aluminium chloride are commonly used in

* To whom all correspondence should be addressed.

谓 +91-11-26596172; fax: +91-11-26521120;

e-mail: kkpant@.chemical.iitd.ac.in

Received 10 March 2004; accepted in revised form 14 November 2005. drinking water treatment to enhance the removal of particulate matter, colloidal, and other dissolved substances via coagulation processes. The use of alum as a coagulant for water treatment often leads to higher concentrations of aluminium in the treated water than in the raw water itself (Srinivasan et al., 1999 and Srinivasan and Viraraghvan, 2002). Typically, a portion of the alum added to the raw water is not removed during treatment and remains as residual aluminium in the treated water. The occurrence of aluminium in treated water has been considered to be an undesirable aspect of the treatment practice (Letterman and Driscoll, 1988; Van Benschoten and Edzwald, 1990). There is considerable concern throughout the world over the levels of aluminium in drinking water sources (raw water) and treated drinking water.

Although a substantial amount of research work is needed before the full implication of the toxic aspects of aluminium are known, it is generally argued that the knowledge of the form and type of species of aluminium in water is of importance since both bioavailability and toxicity are critically dependent on the chemical form of the individual species. A high (3.6 to $6 \mathrm{mg} / \mathrm{l}$ ) concentration of aluminium in treated water gives rise to turbidity which reduces disinfection efficiency, and may precipitate as $\mathrm{Al}(\mathrm{OH})_{3}$ during the course of distribution (Rahman, 1992). These elevated levels of aluminium may have serious ramifications for the fish living in these waters as well for some birds whose diets are made up of insects from the shoreline of affected streams and lakes (Miller et al., 1994). Aluminium is also a known neurotoxicant. It enters the brain, where it contributes to the dialysis encephalopathy syndrome and may contribute to Alzheimer's disease and other neurodegenerative diseases. Aluminium also gives rise to toxicity in the bones and haematopoietic systems in humans (Schecher and Discroll, 1988).

Because of its harmful nature and ill effects, different regulatory agencies have set their own standards for the levels of aluminium in drinking water. The World Health Organisation (WHO) has proposed a guideline value of $0.2 \mathrm{mg} / \ell$. The present drinking water standard for aluminium in the US is $0.2 \mathrm{mg} / \ell$ 
and countries like Canada and Sweden have set their standards at $0.1 \mathrm{mg} / \ell$ (Letterman and Discroll, 1994). In nature, aluminium exists as trivalent oxidation state $\left(\mathrm{Al}^{3+}\right)$. Various attempts have been made by several researchers to find an appropriate technique for aluminium removal (Pesavento et al., 1998). The data provide a compromise between the use of aluminium salts in water treatment and discoloration (due to $\mathrm{Al}(\mathrm{OH})_{3}$ floc) of distributed water.

Suitable low-cost adsorbents having comparable sorption efficiency can be very effective for the removal of aluminium from water. The objective of the present work is to identify a suitable low-cost adsorbent for the removal of aluminium from drinking water. The effect of different process conditions such as $\mathrm{pH}$, initial sorbent/sorbate concentration, and temperature on per cent aluminium removal was investigated to ascertain the mechanism for aluminium adsorption.

\section{Materials and method}

\section{Materials}

The standard stock solution of aluminium $(1000 \mathrm{mg} / \ell)$ used in the study was prepared by dissolving pure $\mathrm{AlCl}_{3}$ supplied by Merck, Germany. Further working aluminium solutions were prepared by diluting the stock solution. $0.01 \mathrm{M}$ hydrochloric acid and $0.1 \mathrm{~N}$ hydroxide solutions were used to adjust the $\mathrm{pH}$ of the solutions.

\section{Adsorbents for aluminium removal}

Three adsorbents tested for aluminium removal from drinking water were rice husk carbon (RHC), commercial granular activated carbon (GAC) and activated rice husk carbon (ARHC). For the preparation of rice husk char, rice husk was pyrolysed in the pyrolyser for $20 \mathrm{~min}$ at $873 \mathrm{~K}$ in the absence of air without any further acid/alkali treatment. Commercially available granulated activated carbon (GAC) was commercially available and was procured from Loba Chemie India.

For the preparation of activated rice husk char, four parts of raw rice husk were treated with three parts of conc. $\mathrm{H}_{2} \mathrm{SO}_{4}$ (by wt.). Charred rice husk was kept at $383 \mathrm{~K}$ in an air oven for $24 \mathrm{~h}$. Carbonised material thus obtained was washed thoroughly with water followed by washing with $0.25 \mathrm{M} \mathrm{NaOH}$ solution to remove excess free acid. The washed material was dried at $373 \mathrm{~K}$ for a period of $24 \mathrm{~h}$. Heat treatment at $873 \mathrm{~K}$ was done in the absence of air in the pyrolyser.

\section{Adsorbent characterisation}

All the sorbents were characterised for their surface area and pore volume on a BET surface area analyser (Micromeritics, USA model ASAP 2010) by $\mathrm{N}_{2}$ adsorption at $77 \mathrm{~K}$. Samples were pretreated with at $378 \mathrm{~K}$ overnight to remove moisture. The sample was degassed at $573 \mathrm{~K}$ for $10 \mathrm{~h}$ under vacuum (Vempati et al., 1995). Specific surface areas of the studied materials were calculated using the standard BET method at the relative pressure range of 0.05 to 0.15 . Pore diameters were estimated from the peak positions of $\mathrm{BJH}$ pore size distribution curves obtained from the adsorption isotherms. The mesoporous volumes were estimated from the amount adsorbed at the relative pressure of about 0.95 . X-ray diffraction (XRD) patterns of the samples were obtained from a Philips Mat. Holland, pw1730/10 diffractometer. The X-ray was generated from a $\mathrm{Cu} \mathrm{K}-\alpha$ target with a current of $30 \mathrm{~mA}$ and a potential of $40 \mathrm{kV}$. The scan was performed between $2 \theta$ values of $10^{\circ}$ and $70^{\circ}$ at a scan rate of $0.06^{\circ} / \mathrm{min}$. For scanning electron microscopy (SEM), sample powder was sprinkled as a thin layer on adhesive tape on a brass bar. The sample was then coated with gold in JEOL (JFC-1100E Ion) sputtering device and transferred into the JEOL (Cambridge 360 scanning electron microscope) sample chamber where an accelerating voltage of $15-40 \mathrm{kV}$ was used for scanning.

\section{Adsorption studies}

Batch experiments were carried out by taking different sorbents in the range of 2 to $10 \mathrm{~g} / \mathrm{l}$ of synthetic aluminium sample of desired initial concentration in a series of reagent flasks at a varying $\mathrm{pH}$ of between 2 and 10 and at $80 \mathrm{r} / \mathrm{min}$. $\mathrm{pH}$ was adjusted either using dilute $\mathrm{NaOH}$ or $\mathrm{HCl}$. Further experiments were conducted at a constant $\mathrm{pH}$ of 4.3 (optimum).

Equilibrium data were collected by taking $100 \mathrm{ml}$ solution of known aluminium concentration $(3.0 \mathrm{mg} / \ell)$ in a series of reagent flasks. To each flask, different adsorbent doses ( 0.2 to $1.0 \mathrm{~g})$ were added. These flasks were shaken for $24 \mathrm{~h}$ to reach equilibrium and filtered. Filtrates were analysed for residual aluminium concentration.

In order to study the thermodynamics of the aluminium adsorption, experiments were carried out at three different temperatures $(303 \mathrm{~K}, 328 \mathrm{~K}$ and $338 \mathrm{~K})$. Residual aluminium concentration was measured and the thermodynamic nature of aluminium studied.

Batch kinetics adsorption experiments were carried out by shaking $1 \mathrm{~g}$ of each sorbent with $100 \mathrm{~m} \ell$ aqueous solution of desired initial sorbate concentration $(3.0 \mathrm{mg} / \ell$ and $5.0 \mathrm{mg} / \ell)$ in a series of reagent flasks at a constant $\mathrm{pH} 4.3$ and a speed of $85 \mathrm{r} / \mathrm{min}$ in a mechanical shaker (Neolab Instruments, Mumbai, India). Samples were withdrawn regularly after a fixed time interval and filtered through $0.45 \mu$ filter paper. The filtrates were analysed for residual aluminium concentration. Similar experiments were carried out by varying solution $\mathrm{pH}$ and temperature.

\section{Determination of aluminium content}

The aluminium concentration was measured by UV-visible spectrophotometer (Varian, Australia model Cary-100 Conc). Aluminium solution buffered with sodium acetate trihydrate solution produces an orange to violet complex with eriochrome cyanine $\mathrm{R}$ dye. The intensity of the colour developed depends on the concentration of the aluminium in the sample. The interference of iron and manganese was eliminated by adding ascorbic acid solution. The wavelength of the operation was kept at 533 $\mathrm{nm}$. Prior to analysis the unit was calibrated with standard solutions of aluminium of different concentrations.

\section{Results and discussion}

\section{Characterisation of sorbents}

The multipoint BET analysis was performed by allowing the sample to degas in a sample tube at $573 \mathrm{~K}$ for $10 \mathrm{~h}$ to remove volatile impurities and moisture which may have adsorbed on the surface previously. The surface area of different sorbents is presented in Table 1. X- ray diffraction of the rice husk char indicated an amorphous peak. As can be seen from Fig. 1, the pyrolysed rice husk has amorphous silica as a base. It can thus be inferred that the char has amorphous silica. The XRD pattern of the sorbents such as rice husk char, activated rice husk char and 


\begin{tabular}{|l|c|c|c|}
\hline \multicolumn{4}{|c|}{ TABLE 1 } \\
Physical chemical characteristics of different \\
low-cost adsorbents
\end{tabular}

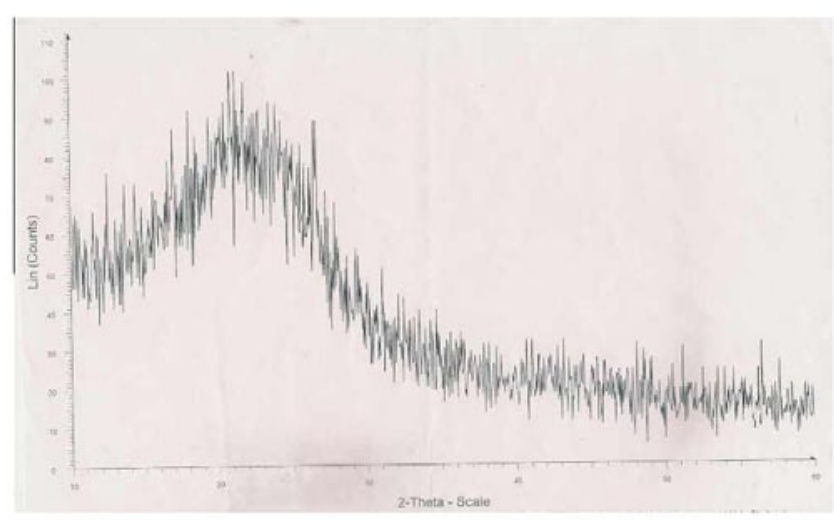

Figure 1

$X R D$ pattern of rice husk char $(R H C)$

commercial activated charcoal gave the XRD patterns that are shown in Fig. 1. Major constituents of rice husk are cellulose, hemi-cellulose, lignin and crude protein. During pyrolysis rice husk is converted into charcoal with carbon and silica as the main constituents.

Scanning electron microscopy (SEM) shows that the rice husk and rice husk charcoal have completely different morphologies. SEM photographs of the rice husk and rice husk charcoal are shown in the Figs. 2, 3 and 4. Figures 2 and 3 show the outer surface of the rice husk and the outer surface of the rice husk char. Figure 4 shows the inner surface of the rice husk char, which seems to be comprised of grains. The size of the grain when calculated was found to be approximately $0.2 \mu \mathrm{m}$. The surface morphology of the rice husk and rice husk char could be a reason behind the adsorptive capacity of the rice husk char.

\section{Comparison of different sorbents for Al removal}

Equilibrium study was performed for analysing the performance of all the adsorbents. The data was generated by varying the adsorbent doses ( 3 to $10 \mathrm{~g} / \ell$ ) at $300 \mathrm{~K}$ and $\mathrm{pH} 4.3$ with activated rice husk char (ARHC), rice husk char (RHC) and commercial activated carbon (GAC) which is shown in Fig. 5. The adsorption capacity of rice husk char and activated rice husk char reached an equilibrium value of 1.6 and $1.2 \mathrm{mg} / \mathrm{g}$, beyond which there was negligible change in residual aluminium concentration. For commercial activated carbon the results indicated that the adsorption is not very favourable with respect to the adsorbent. The maximum adsorption capacity observed $1.6 \mathrm{mg} / \mathrm{g}$ for rice husk char and activated rice husk char (ARHC). More than 97\% of aluminium can be removed with RHC.

The distribution of aluminium between the liquid phase and the solid phase is a measure of the position of equilibrium in the adsorption process and can be expressed by the most popular isotherm models - Langmuir and Freundlich adsorption isotherms.

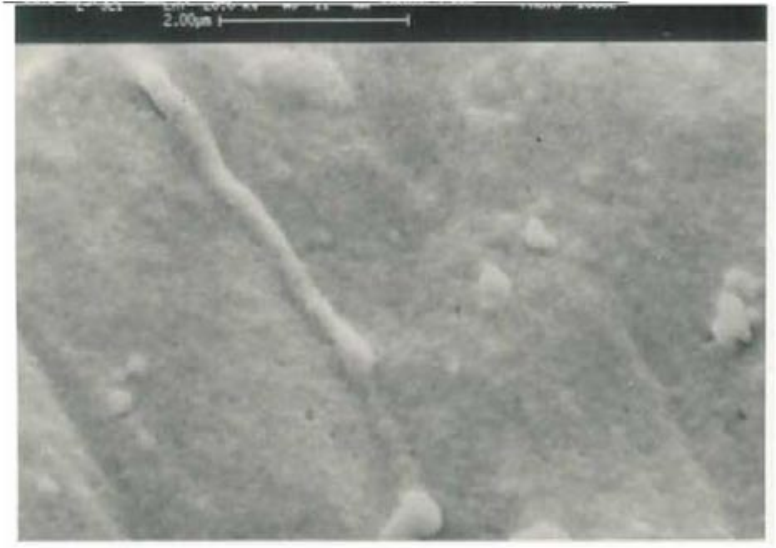

Figure 2

SEM photograph of outer surface of rice husk $(R H)$

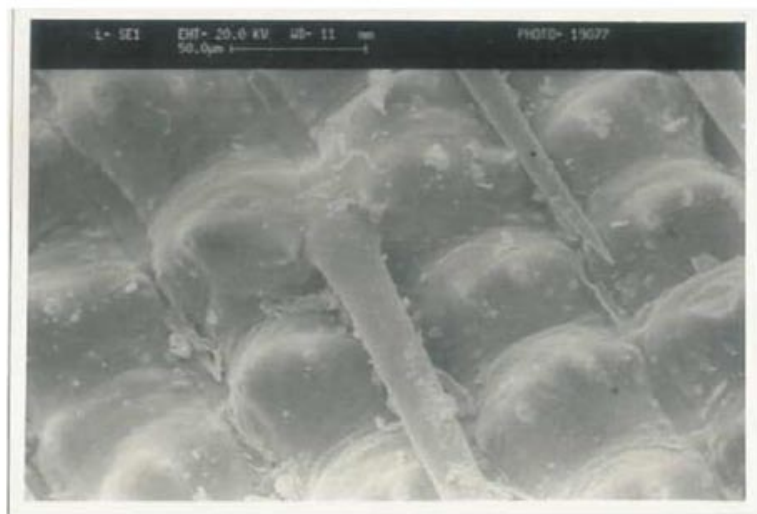

Figure 3

SEM photograph of outer surface of rice husk char (RHC)

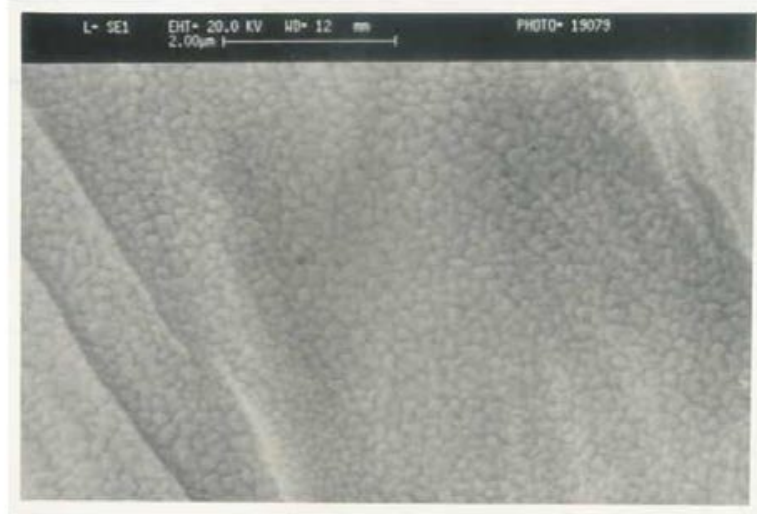

Figure 4

SEM photograph of inner surface of rice husk char (RHC)

The basic assumption of the Langmuir adsorption process is the formation of a monolayer of adsorbate on the outer surface of the adsorbent and after that no further adsorption takes place. A linear form of the Langmuir equation is given by:

$$
\left(\frac{1}{q}\right)=\left(\frac{1}{b q_{m} C_{e}}\right)+\left(\frac{1}{q_{m}}\right)
$$

where:

$q_{e}$ is the amount of adsorbate adsorbed per unit weight of adsorbent $(\mathrm{mg} / \mathrm{g})$ 


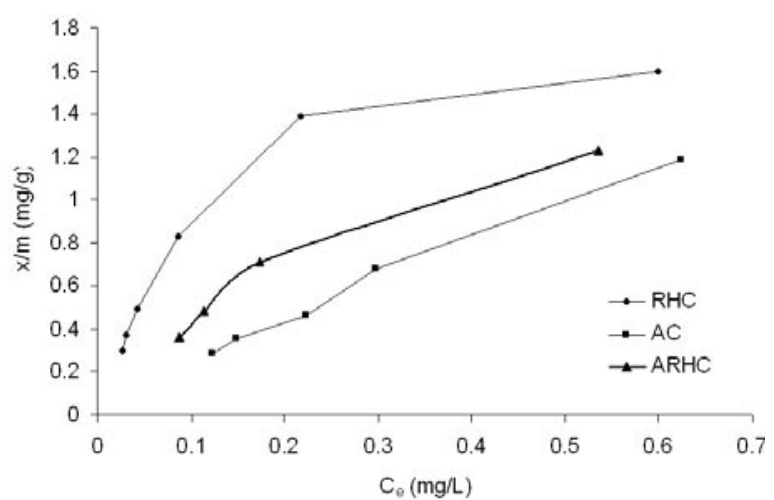

Figure 5

Adsorption isotherm of aluminium on activated rice husk charcoal (RHC) [C $3 \mathrm{mg} / \ell, T 303 \mathrm{~K}, \mathrm{pH} 4.3]$

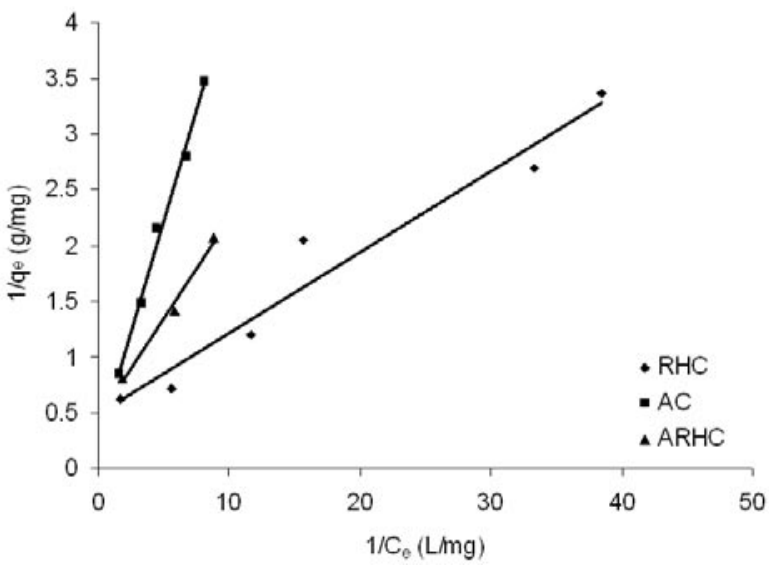

Figure 6

Comparison of Langmuir isotherms of rice husk char (RHC) commercial activated carbon (AC) and activated rice husk char (ARHC) [C $3 \mathrm{mg} / \mathrm{\ell}, \mathrm{T} 303 \mathrm{~K}, \mathrm{pH} 4.3$ ]

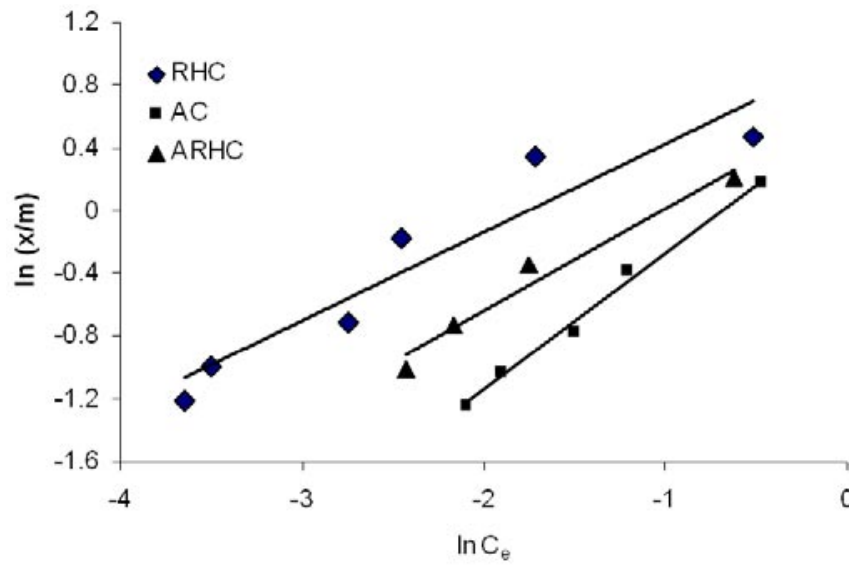

Figure 7

Comparison of Langmuir isotherms of rice husk char (RHC), commercial activated carbon (AC) and activated rice husk char (ARHC) [C $3 \mathrm{mg} / \mathrm{\ell}, \mathrm{T} 303 \mathrm{~K}, \mathrm{pH} 4.3$ ]

$C_{e}$ is the equilibrium concentration of adsorbate $(\mathrm{mg} / \mathrm{l})$ $\mathrm{q}_{\mathrm{m}}$ and $b$ are the Langmuir constants and are the significance of adsorption capacity ( $\mathrm{mg} / \mathrm{g})$ and energy of adsorption $(\ell / \mathrm{mg})$ respectively

$\mathrm{q}_{\mathrm{m}}$ and $\mathrm{b}$ are calculated from the intercept and slope of the plot $1 / \mathrm{q}_{\mathrm{e}}$ and $1 / \mathrm{C}_{\mathrm{e}}$ (Fig. 6)

The Freundlich adsorption isotherm is an indicator of the extent

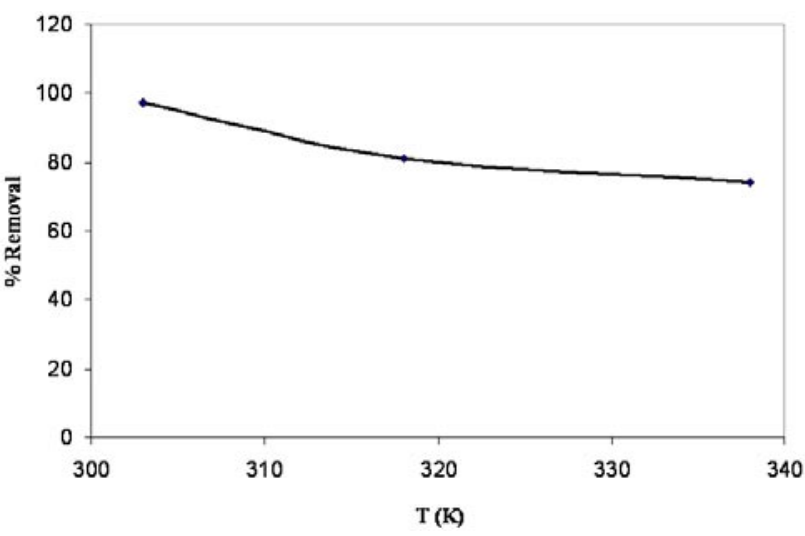

Figure 8

Effect of temperature on \% aluminium removal using rice husk char (RHC) $[\mathrm{pH} \mathrm{4.3,} \mathrm{Co} 3 \mathrm{mg} / \mathrm{l}]$

TABLE 2

Adsorption isotherm constants for different adsorbents

\begin{tabular}{|l|c|c|c|c|}
\hline \multirow{2}{*}{\begin{tabular}{l} 
Temperature \\
\cline { 2 - 5 }
\end{tabular}} & \multicolumn{2}{|c|}{$\begin{array}{c}\text { Freundlich Isotherm } \\
\text { Constants }\end{array}$} & \multicolumn{2}{|c|}{$\begin{array}{c}\text { Langmuir Isotherm } \\
\text { Constants }\end{array}$} \\
\cline { 2 - 5 } & $\begin{array}{c}\mathbf{K} \\
(\mathbf{m g} / \mathbf{g})\end{array}$ & $\mathbf{n}$ & $\begin{array}{c}\mathbf{q}_{\mathbf{m}} \\
(\mathbf{m g} / \mathbf{g})\end{array}$ & $\begin{array}{c}\mathbf{b} \\
(\mathbf{\ell} / \mathbf{m g})\end{array}$ \\
\hline $\mathrm{ARHC}$ & 1.94 & 1.53 & 2.84 & 1.72 \\
\hline $\mathrm{RHC}$ & 9.07 & 1.06 & 9.78 & 1.18 \\
\hline $\mathrm{GAC}$ & 2.20 & 1.15 & 1.35 & 3.21 \\
\hline
\end{tabular}

of heterogeneity of the adsorbent surface. The general form of the isotherm is given as.

$$
q_{e}=K C_{e}^{\frac{1}{n}}
$$

A linear form of this expression is:

$$
\log \left[\frac{x}{m}\right]=\log (K)+\left[\frac{1}{n}\right] \log \left(C_{e}\right)
$$

$\mathrm{K}$ and $\mathrm{n}$ are the Freundlich constants and represent the significance of adsorption capacity and intensity of adsorption respectively. Values of $\mathrm{K}$ and $\mathrm{n}$ were calculated from the intercept and slope of the plot $\log q_{e}$ and $\log C_{e}$ (Fig. 7). The coefficients of the two isotherms as calculated from the plots have been shown in Table 2.

A comparison of isotherm parameters for all three adsorbents was done to find the most suitable adsorbent. It can be seen from Figs. 6 and 7 that adsorption for the aluminium onto rice husk char and commercial activated carbon could be explained better by the Freundlich isotherm whereas adsorption onto activated rice husk charcoal was explained by the Langmuir isotherm. The value of adsorption parameters also gives an indication that rice husk char (RHC) is the most suitable adsorbent for aluminium removal from water. From the Langmuir and Freundlich isotherm constants, it can be inferred that rice husk char has the highest adsorption capacity and intensity and is thus the most suitable for the aluminium adsorption. The aluminium sorption for rice husk char was higher than the other two sorbents, thereby indicating that the rice husk char is better suited for aluminium removal compared to other adsorbents.

\section{Thermodynamic study}

In order to understand the mechanism of aluminium removal, adsorption experiments were carried out at three different 
temperatures, 303,318 and $338 \mathrm{~K}$ at $\mathrm{pH} 4.3$. It can be observed from Fig. 8 that the percentage adsorption decreases from $97.3 \%$ to $74.1 \%$ for the feed aluminium concentration of $3 \mathrm{mg} / \ell$ when the temperature was raised from $303 \mathrm{~K}$ to $338 \mathrm{~K}$. The thermodynamic parameters $\Delta \mathrm{G}^{\circ}, \Delta \mathrm{S}^{\circ}$ and $\Delta \mathrm{H}^{\circ}$ for this adsorption process have been determined by using the following equations:

$$
\begin{aligned}
& \Delta \mathrm{G}^{\mathrm{o}}=\Delta \mathrm{H}^{\circ}-\mathrm{T} \Delta \mathrm{S}^{\mathrm{o}} \\
& \log \left(\frac{q}{C_{e}}\right)=\frac{\Delta S^{o}}{2.303 R}-\frac{\Delta H^{o}}{2.303 R T}
\end{aligned}
$$

where:

$\mathrm{q}$ is the amount of aluminium adsorbed per unit mass of rice husk char (mmol/g),

$\mathrm{C}_{\mathrm{e}}$ is the equilibrium sorbate concentration $(\mathrm{mg} / \mathrm{l})$

$\mathrm{T}$ is the temperature $\mathrm{K} . \mathrm{q} / \mathrm{C}_{\mathrm{e}}$ is called the adsorption affinity.

The values of Gibb's free energy $\left(\Delta \mathrm{G}^{\circ}\right)$ have been calculated from the enthalpy of adsorption $\left(\Delta \mathrm{H}^{\circ}\right)$ and the entropy of adsorption $\left(\Delta \mathrm{S}^{\circ}\right)$. Values of enthalpy of adsorption and entropy were obtained from the plot of $\log \left(\mathrm{q} / \mathrm{C}_{\mathrm{e}}\right)$ vs. 1/T as shown in Fig. 9. Once these parameters were obtained, the $\Delta \mathrm{G}^{\circ}$ values as determined from Eq. (4) were $-4.71 \mathrm{~kJ} / \mathrm{mol},-1.85 \mathrm{~kJ} / \mathrm{mol}$ and $1.77 \mathrm{~kJ} /$ mol at temperatures of $303 \mathrm{~K}, 318 \mathrm{~K}$ and $338 \mathrm{~K}$ respectively. The negative value of $\Delta \mathrm{H}^{0}(-62.55 \mathrm{~kJ} / \mathrm{mol})$ shows aluminium adsorption on rice husk charcoal to be exothermic. This can also be inferred from the fact that the adsorption of aluminium from water decreases as the temperature is increased. A negative value of $\Delta \mathrm{S}^{0}(-190.86 \mathrm{~J} / \mathrm{mol} \cdot \mathrm{K})$ corresponds to a decrease in the degree of freedom of adsorbed species. Negative values of $\Delta \mathrm{G}^{0}$ confirm feasibility of adsorption process and spontaneous nature of adsorption.

\section{Effect of pH}

$\mathrm{pH}$ has a very significant role on the adsorption of aluminium as it affects the solubility of aluminium to a great extent. One of the major factors that can affect the adsorption process is solution $\mathrm{pH}$, hence it becomes necessary to determine the $\mathrm{pH}$ at which maximum adsorption takes place; $\mathrm{pH}$ was adjusted either by diluted $\mathrm{NaOH}$ or $\mathrm{HCl}$. The effect of $\mathrm{pH}$ on percentage aluminium removal using rice husk char at an initial sorbate concentration of $3 \mathrm{mg} / \ell$ and sorbent dose of $4 \mathrm{~g} / \ell$ was studied and is shown in Fig. 10. From this figure, it was observed that optimal $\mathrm{pH}$ for aluminium adsorption is $4.2 \pm 0.2$ and that the removal is insignificant at a $\mathrm{pH}$ of less than 3.5. This can be attributed to the fact that at lower $\mathrm{pH}$ the active sites become protonated and adsorption is restricted. Maximum aluminium removal was observed at $\mathrm{pH}$ 4 and then remained nearly constant. A maximum of up to $90 \%$ of aluminium can be removed under these conditions. Therefore further experiments were carried out at $\mathrm{pH} 4.3$ where maximum (>98\%) removal of aluminium was observed (Fig. 10).

A plot of per cent aluminium removal vs. initial concentration at $\mathrm{pH} 4.3$ is shown in Fig. 11. As the concentration of aluminium increases in the water, percentage removal of aluminium decreases significantly. Above $10 \mathrm{mg} / \ell$ concentration, rice husk char was not very effective. At $10 \mathrm{mg} / \ell$, rice husk char (RHC) showed less than 50\% aluminium removal.

\section{Adsorption kinetics}

The kinetics of adsorption of aluminium on rice husk char has been described by the first-order rate kinetics model. The
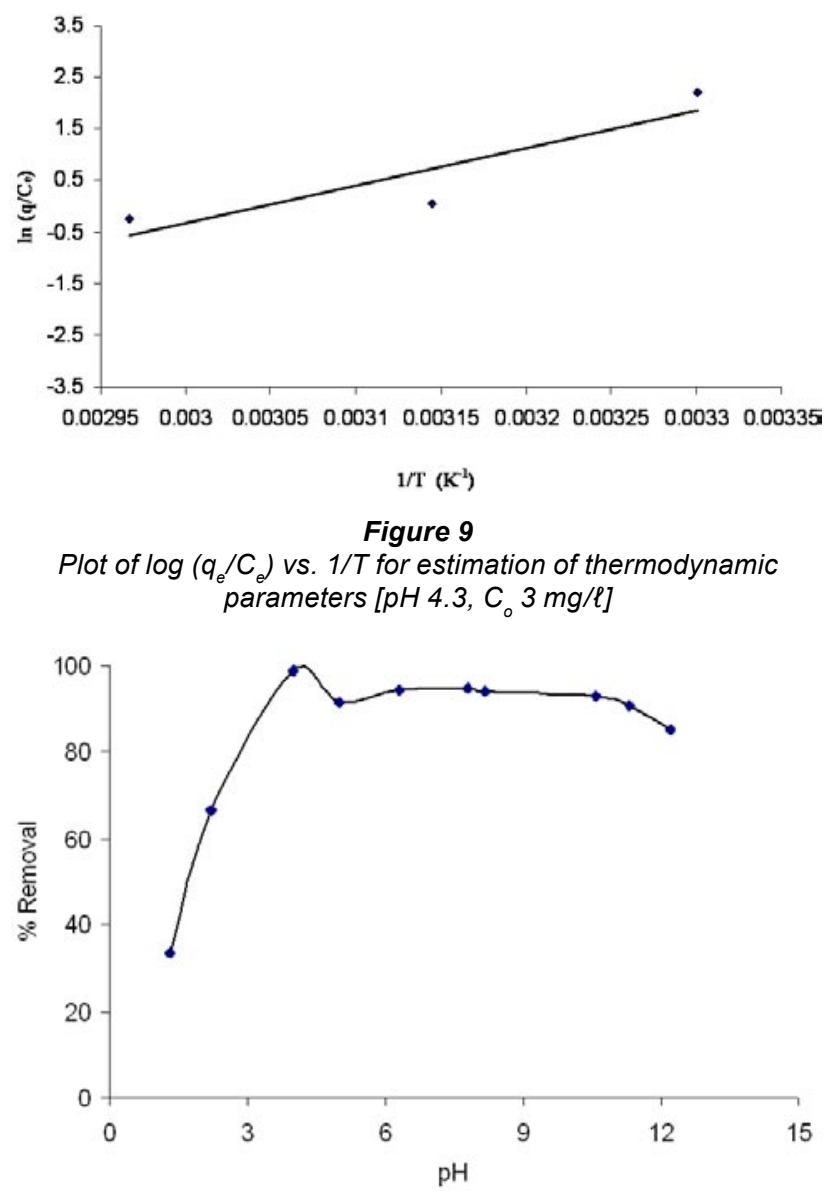

Figure 10

Effect of $\mathrm{pH}$ on \% removal of aluminium by rice husk charcoal (RHC) [C $3 \mathrm{mg} / \ell, T 303 \mathrm{~K}]$

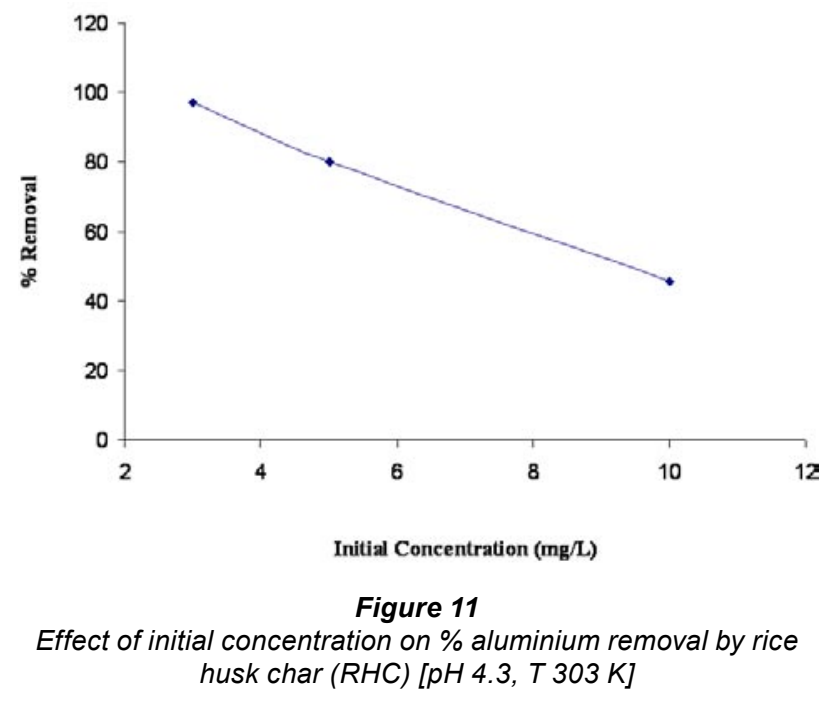

Lagergren equation for first-order kinetics is given as follows (Singh and Pant, 2004)

$$
\log \left(q_{e}-q\right)=\log \left(q_{e}\right)-\left(\frac{K_{a d}}{2.303}\right) t
$$

where:

$\mathrm{q}_{\mathrm{e}}$ and $\mathrm{q}$ are the amounts of aluminium adsorbed $(\mathrm{mg} / \mathrm{g})$ at equilibrium and at any time $t$

$\mathrm{K}_{\mathrm{ad}}$ is the first-order rate constant $\left(\mathrm{h}^{-1}\right)$ 


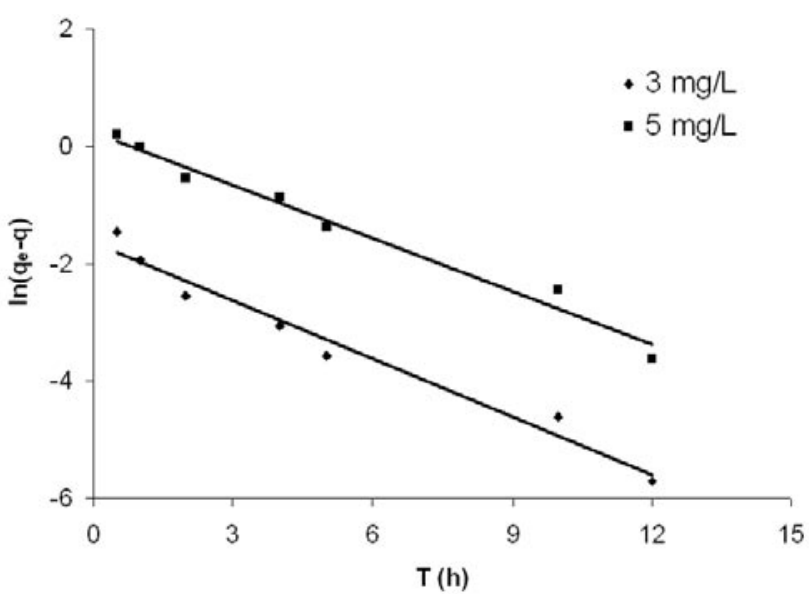

Figure 12

Estimation of first-order rate constants for aluminium adsorption [pH 4.3, T $303 \mathrm{~K}$ )

A plot of $\log \left(q_{e}-q\right)$ vs. $t$ gives a straight line for first-order kinetics and is shown in Fig. 12 for initial aluminium concentrations of 3 and $5 \mathrm{mg} / \mathrm{l}$ respectively. Results obtained from this study showed that first-order rate constants $(0.30 \pm 0.02 / \mathrm{h})$ are independent of initial sorbate concentration. The values of first-order rate constants as obtained from the slope of the curve were 0.32 / $\mathrm{h}$ and $0.30 / \mathrm{h}$ respectively.

\section{Conclusions}

The following conclusions were drawn from the present study. Among the various sorbents studied, rice husk char has shown the maximum adsorption capacity for aluminium compared to activated rice husk char and activated carbon. The solution $\mathrm{pH}$ has a very significant affect on the adsorption of aluminium. The maximum removal of the aluminium took place at a $\mathrm{pH} 4.2 \pm 0.2$. The adsorption capacity of rice husk char decreased with the increase in aluminium concentration. Above $10 \mathrm{mg} / \ell$ aluminium concentration, rice husk char is not very effective in removing aluminium. Good correlation coefficients and the closeness between experimental and theoretical values of $q_{e}$ showed that the aluminium adsorption followed first-order kinetics. The adsorption data followed both Freundlich and Langmuir isotherms. Thermodynamic analysis of the alumi- nium adsorption on rice husk char showed that adsorption is an exothermic process. Randomness decreased with an increase in the temperature.

\section{Acknowledgements}

The financial support provided by the Council for Scientific \& Industrial Research (CSIR) India for the research work is greatly acknowledged.

\section{References}

DENIZLI A, SAY R and PIKIN E (2003) Removal of aluminium by Alizarin Yellow attached magnetic poly (2-hydroxyethyl methacrylate) beads. React. Funct. Polym. 55 (1) 99-107.

LETTERMAN RD and DISCROLL CT (1994) Control of Residual Aluminum in Filtered Water. AWWA RF Report, AWWA, Denver, CO 80235.1-93.

LETTERMAN RD and DRISCOLL CT (1988) Survey of residual aluminum in filtered water. $J$. AWWA 80 (4) 154-158.

MILLER GR, KOPLER CF, KELTY CK, SOBER AJ and ULMER SN (1994) The occurrence of aluminum in drinking water. J. $A W W A$ 76 (1) 184.

PESAVENTO M, ALBERTI G and BIEUZ R (1998) Investigation of the speciation of aluminium in drinking waters by sorption on a strong anionic-exchange resin AG1X8. Anal. Chim. Acta 367 (1-3) 215-222.

RAHMAN A (1992) M.Sc Thesis, State University of New York at Buffalo, NY.

SCHECHER WD and DISCROLL CT (1988) An evaluation of equilibrium calculations within acidification models: The effect of uncertainty in measured chemical components. Water Resour. Res. 24 533-542.

SINGH TS and PANT KK (2004) Equilibrium, kinetics and thermodynamic studies for adsorption of As(III) on activated alumina. Sep. Pur. Technol. 36 (2) 139-147.

SRINIVASAN PT and VIRARAGHAVAN T (2002) Characterisation and concentration profile of aluminium during drinking-water treatment. Water SA 28 (1) 99-106.

SRINIVASAN PT, VIRARAGHAVAN T and SUBRAMANIAN KS (1999). Aluminium in drinking water: An overview. Water $S A \mathbf{2 5}$ (1) 48-57.

VAN BENSCHOTEN JE and EDZWALD JK (1990) Measuring aluminum during water treatment: Methodology and application. J. $A W W A 82$ (5) 71-79.

VEMPATI KR, MUSTHYALA SC, MOLLAH MYA and COCKE DA (1995) Surface analyses of pyrolysed rice husk using scanning force microscopy. Fuel 74 (11) 1722-1725. 